\title{
Pendekatan yang Dilakukan Komisi Pengawas Persaingan Usaha Menentukan Pelanggaran dalam Hukum Persaingan Usaha
}

\author{
Alum Simbolon \\ Universitas Katolik Santo Thomas Medan \\ Jln Setia Budi No 479 F Tanjung Sari Medan \\ simbolon_alum@yahoo.com
}

\begin{abstract}
The issue in this research is concerning with the approach used by KPPU (Commission for Business Competition) in determining the violation in business competition regulations. This aims to observe the approach is used by KPPU in determining the violation in business competition regulations. This research applies a normative-judicial method. The result of this research shows that the approach used by KPPU in determining the violation in business competition regulations in this case is judicial per se illegal approach. The implementation of per se illegal to the action of determining price conducted by KPPU is found accurate as it has been accommodated by market.
\end{abstract}

Key words: Business competition regulations, legal approach, per se illegal and rule of reason.

\begin{abstract}
Abstrak
Permasalahan dalam penelitian ini adalah pendekatan apa yang dilakukan oleh Komisi Pengawas Persaingan Usaha (KPPU) dalam menentukan pelanggaran terhadap hukum persaingan usaha. Penelitian ini bertujuan untuk mengetahui pendekatan apa yang dilakukan oleh Komisi Pengawas Persaingan Usaha (KPPU) dalam menentukan pelanggaran terhadap hukum persaingan usaha. Metode yang digunakan dalam penelitian ini adalah yuridis normatif. Hasil penelitian menunjukkan bahwa pendekatan yang dilakukan oleh KPPU dalam menentukan pelanggaran terhadap hukum persaingan usaha dalam kasus ini yaitu pendekatan yuridis per se illegal. Penerapan per se illegal terhadap tindakan penetapan harga yang dilakukan oleh KPPU sudah tepat karena penetapan harga tersebut diakomodir oleh pasar.
\end{abstract}

Kata Kunci : Hukum persaingan usaha, pendekatan hukum, per se illegal dan rule of reason 


\section{Pendahuluan}

Pada awal pendiriannya, Komisi Pengawas Persaingan Usaha (selanjutnya disebut dengan KPPU) mengemban tugas yang teramat berat dalam menghadapi dinamisnya dunia usaha di tengah situasi krisis multidimensi yang menyelimuti Indonesia waktu itu. Saat itu arus konflik dunia usaha Indonesia sangat kuat. Praktik persaingan usaha yang tidak sehat dianggap jamak 'lumrah', ditambah lagi dengan adanya persekongkolan antara pelaku usaha dengan pemegang kekuasaan. Untuk menjalankan tugasnya dengan baik, undang-undang memberikan amunisi berupa kewenangan yang luas kepada KPPU. Selain itu, KPPU juga diberikan rentang waktu yang terbatas dalam menangani suatu perkara, hal ini bertujuan untuk dapat menjamin kepastian berusaha.

Dalam melaksanakan Undang-Undang Nomor 5 Tahun 1999 tentang Larangan Praktek Monopoli dan Persaingan Usaha Tidak Sehat (selanjutnya disebut dengan UULPM), KPPU dapat menangani perkara berdasarkan pada dua mekanisme kerjanya yaitu berdasarkan laporan yang masuk ke KPPU ataupun atas inisiatif KPPU dalam melihat fenomena yang terjadi dalam dunia usaha. Keputusan yang dihasilkan KPPU bersifat mengikat tetapi tidak final, sebab masih dimungkinkan kepada pihak terlapor untuk mengajukan keberatan atas putusan KPPU kepada Pengadilan Negeri tempat terlapor berdomisili seperti diatur pada Pasal 44 ayat (2) UULPM, bahkan proses hukum ini juga dapat berlangsung hingga tingkat Mahkamah Agung (MA). Proses tersebut menunjukkan bahwa terdapat fungsi kontrol yang berimbang antara KPPU, PN, dan MA dalam mengimplementasikan penegakan hukum persaingan usaha.

KPPU dalam melaksanakan tugas dan wewenangnya memerlukan adanya arah pandang yang jelas, sehingga apa yang menjadi tujuannya dapat dirumuskan dengan seksama pencapaiannya dan dapat direncanakan dengan tepat. Arah pandang KPPU tersebut sebagai lembaga independen yang mengemban amanat UULPM adalah: "Menjadi Lembaga Pengawas Persaingan Usaha yang Efektif, Kredibel untuk Meningkatkan Kesejahteraan Rakyat". ${ }^{1}$

Pasal 30 ayat (1) UULPM menentukan bahwa KPPU mengawasi pelaksanaan UULPM; (2) menentukan, bahwa KPPU merupakan lembaga independen yang terlepas dari pengaruh kekuasaan pemerintah serta pihak lain; (3) menentukan,

\footnotetext{
${ }^{1}$ www//kppu.go.id, diakses pada tgl. 30 November 2002.
} 
bahwa dalam pelaksanaan tugasnya KPPU bertanggung jawab kepada Presiden. Anggota KPPU diangkat oleh Presiden setelah mendapatkan persetujuan Dewan Perwakilan Rakyat. Tugas dan Wewenang Komisi diatur dalam Pasal 35 dan Pasal 36 UULPM secara rinci, kemudian ditegaskan kembali dalam Pasal 4 Keputusan Presiden Nomor 75 Tahun 1999. Dalam rangka pelaksanaan Pasal 34 ayat (1) UULPM maka dikeluarkan Keputusan Presiden Republik Indonesia No. 75 Tahun 1999 tentang Komisi Pengawas Persaingan Usaha. Melalui Keppres No. 75 Tahun 1999 Pasal 1 ayat (1) dibentuk Komisi Pengawas Persaingan Usaha yang selanjutnya disebut dengan Komisi. Ayat (2) Keppres 75 Tahun 1999 menyatakan bahwa Komisi sebagaimana dimaksud pada ayat (1) merupakan lembaga non struktural yang terlepas dari pengaruh kekuasaan pemerintah serta pihak lain. Pasal 1 angka (18) UULPM memberikan arti Komisi Pengawas Persaingan Usaha adalah komisi yang dibentuk untuk mengawasi pelaku usaha dalam menjalankan kegiatan usahanya agar tidak melakukan praktek monopoli atau persaingan usaha tidak sehat. Keppres No. 75 Tahun 1999 tentang KPPU ini telah diubah dengan Perpres No. 80 Tahun 2008 tentang Perubahan Atas Keputusan Presiden No. 75 Tahun 1999 tentang Komisi Pengawas Persaingan Persaingan Usaha.

\section{Rumusan Masalah}

Permasalahan dalam penelitian ini adalah pendekatan apa yang digunakan oleh Komisi Pengawas Persaingan Usaha (KPPU) dalam menentukan pelanggaran terhadap hukum persaingan usaha?

\section{Tujuan Penelitian}

Penelitian ini bertujuan untuk mengetahui pendekatan apa yang digunakan oleh Komisi Pengawas Persaingan Usaha (KPPU) dalam menentukan pelanggaran terhadap hukum persaingan usaha.

\section{Metode Penelitian}

Data yang digunakan dalam penelitian ini adalah bahan hukum sekunder yaitu penelitian hasil studi kepustakaan maupun data primer sebagai hasil studi dari lapangan, dianalisis secara kualitatif, karena penelitian ini dikategorikan sebagai penelitian hukum normatif, di mana pendekatannya lebih bersifat abstrak teoritis. 
Sedangkan data primer dari KPPU, Kantor Perwakilan Daerah (KPD) KPPU Medan. Data primer yaitu data yang langsung diperoleh dari sumber data di lapangan (field research). ${ }^{2}$

Bahan hukum primer berupa, norma/kaidah baik hukum tertulis maupun tidak tertulis. ${ }^{3}$ Dewasa ini penelitian hukum tidak hanya dilakukan dengan penelitian kepustakaan (penelitian hukum normatif) saja, tetapi dilengkapi dengan penelitian lapangan (penelitian empiris) ${ }^{4}$ jika diperlukan. Penelitian hukum berhubungan dengan apa yang seharusnya, menjawab pertanyaan bagaimanakah yang seharusnya. Ilmu hukum membawa pesan 'demikianlah anda seharusnya berbuat' (bersifat perspektif), bukan 'demikianlah adanya'.

\section{Hasil Penelitian dan Pembahasan}

KPPU melakukan pendekatan untuk menganalisis apakah terdapat indikasi pelanggaran terhadap UULPM yang dilakukan pelaku usaha dalam menjalankan kegiatan usahanya. Pendekatan pertama adalah pendekatan yuridis (hukum) yang kedua adalah pendekatan ekonomi. ${ }^{6}$ Secara yuridis (hukum) terdapat dua pendekatan yang dapat digunakan yaitu per se illegal dan rule of reason. Selain digunakan untuk menganalisis, apakah terdapat indikasi pelanggaran terhadap UULPM pendekatan hukum ini juga dapat digunakan oleh KPPU untuk menghukum pelaku usaha yang secara nyata melanggar ketentuan UULPM.

Pendekatan ekonomi KPPU dapat melakukan analisis terhadap pelanggaran yang dilakukan oleh pelaku usaha berdasarkan pada relevan market (pasar terkait), market power (kekuatan pasar), barrier to entry (hambatan terhadap pasar) pricing strategic (strategi harga) yang diberlakukan oleh pelaku usaha. Pendekatan ekonomi ini dilakukan oleh KPPU untuk menentukan apakah yang dilakukan oleh pelaku usaha ini berpengaruh kepada tingkat persaingan atau tidak serta untuk menentukan apakah tindakan pelaku usaha akan mengakibatkan kondisi perekonomian semakin memburuk atau tidak. ${ }^{7}$

\footnotetext{
${ }^{2}$ Soedikno Mertokusumo, Penemuan Hukum Sebuah Pengantar, Liberty, Yogyakarta, 1996, hlm. 30.

${ }^{3}$ Ibid.

${ }^{4}$ Ibid.

${ }^{5}$ Ibid., hlm. 28.

${ }^{6}$ L. Budi Kagramanto, Larangan Persekongkolan Tender (Perspektif Hukum Persaingan Usaha), Penerbit Srikandi, 2008, hlm. 219.

${ }^{7}$ Ibid.
} 
Pendekatan yang dilakukan untuk melihat apakah pelaku usaha diduga telah melakukan pelanggaran UULPM atau tidak dengan melihat pada: a. struktur pasar (market structur), misalnya bila perusahaan memiliki pangsa pasar lebih dari indikator yang ditetapkan oleh undang-undang, yaitu 50\% untuk 1 pelaku usaha atau 75\% untuk dua pelaku usaha atau lebih; b. perilaku (behavior) misalnya melalui tindakan atau perjanjian yang dilakukan oleh pelaku usaha tersebut dengan pelaku usaha persaingan atau tidak, contohnya tindakan jual rugi (predatory pricing), perjanjian distributor dan sebagainya. ${ }^{8}$

Pendekatan yang dipergunakan di berbagai negara yang telah memberlakukan hukum persaingan adalah menitikberatkan pada pendekatan perilaku (behavior) yang bersifat anti persaingan. Hukum persaingan mengenal dua kriteria pendekatan dalam menentukan hambatan dalam suatu pasar yaitu dengan pendekatan yang disebut Per se Illegal (Per se Violations atau Perse Rule) ataupun pendekatan Rule of Reason dikatakan:

Rule of Reason is a legal approach by competition authorities or the courts where an attempt is made to evaluate the procompotitive features business practices againts its anticompetitive effects to decide wether or not the pactice should be prohibited. Some market restriction which prima fair give rise to competition issues may on further examination be found to have valid efficiency-enharcing benefits. For example, a manufacturer may restrict supply of a product in different geographic markets only to existing retailers so that they earn higher profits and have an incentive to advertise the product and provide better service to costumer. This may have the effect of expending the demand for the manufacturer's product more than the increase in quantity demanded at a lower price. The opposite of the Rule of Reason approach is to declare certain business practices per se illegal, that is always illegal. ${ }^{9}$

Kenyataan dalam kasus-kasus persaingan, penggunaan kedua pendekatan ini tidak mudah untuk diterapkan. Tidak semua orang mempunyai persepsi yang sama terhadap pengertian yang menyatakan suatu tindakan dinyatakan mutlak melanggar ataupun dapat diputuskan setelah melihat argumentasi alasan rasional tindakannya. Banyak pendekatan yang dicoba oleh para akademisi, ahli hukum persaingan praktisi hukum untuk menetapkan aplikasi ini walaupun tidak bersifat mutlak. Selama ini, perdebatan masih tetap berlangsung dalam hukum persaingan ketika menentukan ukuran faktor "reasonableness" tersebut. Faktor-faktor yang perlu diperhatikan untuk mengukurnya adalah: a. akibat yang ditimbulkan dalam pasar persaingan; b. pertimbangan bisnis yang mendasari tindakan tersebut; c. kekuatan

\footnotetext{
${ }^{8}$ Ningrum Sirait, Hukum Persaingan di Indonesia, Pustaka Bangsa Press, Medan. 2004, hlm. 77.

${ }^{9}$ Ibid. hlm. 78
} 
pangsa pasar (market power); d. alternatif yang tersedia; e. tujuan dari tindakan tersebut. ${ }^{10}$

Suatu tindakan atau perilaku baru dapat dinyatakan bersifat anti persaingan (anti competitive behavior) adalah dengan melihat akibat dari tindakan yang dilakukan, misalnya penetapan harga. Dalam ukuran per se illegal maka pihak yang menuduh melakukan pelanggaran harus membuktikan bahwa tindakan itu benar dilakukan tanpa harus membuktikan efek atau akibatnya. Tindakan yang dilakukan itu tidak mempunyai pertimbangan bisnis atau ekonomi yang rasional dapat dibenarkan, misalnya penetapan harga bertujuan untuk mengelakkan persaingan. Dalam hal ini pemisahan yang tegas antar pendekatan per se illegal dan rule of reason dinyatakan dengan bright line test (per se rules). Selebihnya adalah dengan melihat faktor yang mempengaruhi apakah suatu tindakan yang mempengaruhi dengan melihat unsur alasan atau "reasonabless" dengan jalan mengevaluasi tujuan akibat dari tindakannya dalam suatu pasar atau proses persaingan. ${ }^{11}$

Pengadilan di Amerika Serikat (AS) juga mengatakan analisis yang sifatnya menyeluruh dalam pendekatan rule of reason dengan mempertimbangkan faktor akibat secara komprehensif, apakah akibatnya menguntungkan ataupun menghambat persaingan. Pasal-pasal dalam UULPM, pendekatan per se illegal ini terlibat melalui pasal yang sifatnya imperatif dengan interpretasi yang memaksa. Kebalikan dari pendekatan per se illegal maka pendekatan rule of reason menggunakan alasan pembenaran apakah tindakan yang dilakukan walaupun bersifat anti persaingan tetapi mempunyai alasan pembenaran yang menguntungkan dari pertimbangan sosial, keadilan ataupun efek yang ditimbulkanya serta unsur maksud (intent). Para ahli hukum persaingan mencoba untuk menganalisis bentuk pendekatan tersebut dalam berbagai pendekatan dengan tujuan untuk mempermudah menentukan apakah suatu tindakan jelas bersalah atau masih dapat diterima alasan pembenarannya. ${ }^{12}$

Pendekatan per se illegal pihak yang menuduh melakukan pelanggaran hanya harus membuktikan bahwa tindakan itu benar dilakukan tanpa harus membuktikan efek atau akibatnya. Tindakan yang dilakukan itu juga tidak mempunyai pertimbangan bisnis atau ekonomi yang rasional dapat dibenarkan, misalnya penetapan harga hanya dengan tujuan untuk mengelakkan persaingan. ${ }^{13}$

\footnotetext{
${ }^{10}$ Ibid, hlm. 79.

${ }^{11}$ Ibid

${ }^{12}$ Ibid. hlm. 80.

${ }^{13}$ Ibid., h. 81.
} 
Guna mengetahui apakah suatu tindakan pelaku usaha merupakan pelanggaran terhadap UULPM, maka pendekatan per se illegal dan rule of reason menjadi acuan. Penerapan kedua pendekatan tersebut dipergunakan di beberapa negara yang telah lama memberlakukan aturan hukum persaingan, misalnya AS dan negara-negara yang bergabung dalam pasar Uni Eropa. ${ }^{14}$

Pendekatan yang digunakan oleh otoritas KPPU untuk menganalisis apakah terdapat indikasi pelanggaran terhadap UULPM yang dijalankan pelaku usaha dalam menjalankan kegiatan usahanya adalah pendekatan yang diuraikan berikut secara detail. Pendekatan pertama adalah pendekatan yuridis (hukum) yang kedua adalah pendekatan ekonomi. ${ }^{15}$

\section{Pendekatan Yuridis dan Pendekatan Ekonomi}

\section{Pendekatan Per se Illegal}

Kata 'per se' dalam per se illegal berasal dari bahasa latin, artinya by himself, in itself, taken alone, by means of it self, in isolation, unconnected with other matters sebagainya, sebagaimana dinyatakan Henry Campbell Black. ${ }^{16}$ Kissane \& Benerefo, ${ }^{17}$ mengatakan bahwa suatu perbuatan dalam pengaturan persaingan usaha dikatakan sebagai illegal secara per se (per se illegal) apabila: “...pengadilan telah memutuskan secara jelas adanya anti persaingan, di mana tidak diperlukan lagi analisis terhadap fakta-fakta tertentu dari masalah yang ada guna memutuskan, bahwa tindakan tersebut telah melanggar hukum." 18 Dengan demikian dapat dikatakan bahwa ada kategori terhadap perbuatan yang oleh pengadilan dianggap secara konkrit bersifat anti persaingan ataupun menjurus pada praktek monopoli, sehingga analisis terhadap kenyataan yang ada di sekitar perbuatan tersebut telah melanggar hukum.

Yahya Harahap mengatakan bahwa per se illegal pun artinya "sejak semula tidak sah", oleh karenanya perbuatan tersebut merupakan suatu perbuatan yang "melanggar hukum". Sehingga perbuatan itu dengan sendirinya telah melanggar ketentuan yang sudah diatur, jika perbuatan tersebut telah memenuhi rumusan dalam undang-undang persaingan usaha tanpa ada suatu pembuktian, itulah yang

\footnotetext{
${ }^{14}$ Tri Anggraini, Per Se Illegal dan Rule of Reason, UI Press, 2003, Jakarta, hlm. 7.

${ }^{15}$ L Budi Kagramanto, Op. Cit., hlm. 219.

${ }^{16}$ Ibid. hlm. 223.

${ }^{17}$ Ibid.

${ }^{18}$ Ibid.
} 
disebut dengan per se illegal. ${ }^{19}$ Lawrence Anthony Sullivan ${ }^{20}$ mengatakan Per se illegal adalah suatu pendekatan yang secara an sich lebih menitik-beratkan kepada prilaku pelaku usaha tanpa terlalu memperhitungkan kepentingan ekonomi sosial secara lebih luas. Pemahaman pendekatan ini, setiap penetapan harga di antara para pelaku usaha, baik yang berakibat langsung maupun tidak langsung terhadap harga, tetap dianggap bertentangan dengan UULPM. Dibandingkan dengan pendekatan rule of reason lebih berorientasi pada prinsip efisiensi, yakni yang memperhitungkan akibat negatif (kerugian ekonomis) positif (keuntungan ekonomis) dari tindakan tertentu terhadap proses persaingan.

Perjanjian-perjanjian monopoli maupun kegiatan-kegiatan yang bersifat menghambat dilarang oleh UULPM perlu dijelaskan bahwa larangan terhadap tindakan monopoli atau persaingan curang pada garis besarnya dilakukan dengan memakai salah satu dari dua teori berikut: Larangan yang bersifat Per Se (Per Se Illegal) Larangan yang bersifat Rule of Reason..$^{21}$

\section{Larangan yang bersifat Per se (Per Se Illegal)}

Larangan-larangan yang bersifat Per Se yaitu larangan yang jelas tegas yaitu perilaku yang sangat mungkin merusak persaingan. Perilaku ini mutlak dilarang tanpa mensyaratkan adanya pembuktian mengenai akibat-akibatnya. Tegasnya dengan teori Per Se pelaksanaan dari setiap tindakan yang dilarang adalah bertentangan dengan hukum yang berlaku. Perbuatan yang dilarang dengan Per Se Rules, maupun Rule of Reason pada hukum persaingan di suatu negara tidak selalu sama dengan hukum di negara lain. Perbedaan bentuk larangan pada dasarnya dipengaruhi oleh pertimbangan-pertimbangan kepatutan keadilan, efisiensi kepastian hukum, serta manfaat bagi masyarakat. ${ }^{22}$

Penerapan Per Se Rule yang berlebihan dapat menjangkau perbuatan yang sebenarnya tidak merugikan bahkan mendorong persaingan. Haruskah seseorang dihukum karena melakukan perbuatan yang dianggap membahayakan persaingan

\footnotetext{
${ }^{19}$ M. Yahya Harahap, Beberapa Tinjauan Tentang Permasalaban Hukum (II), Citra Aditya Bakti, Bandung, 1997, hlm. 28.

${ }^{20}$ Tri Anggraini, Op. Cit., hlm. 7.

${ }^{21}$ Susanti, Naskah Akademis Tentang Persaingan Usaha Anti Monopoli, Mahkamah Agung RI, Jakarta, 2005, hlm. 49.

${ }^{22} \mathrm{Hal}$ ini juga berkaitan dengan budaya suatu bangsa sehingga hukum persaingan antara bangsa yang satu dengan yang lain tidak dapat dinyatakan sama. Indonesia malah agak berbeda apalagi dikaitkan dengan dasar Negara Pancasila, yang sesungguhnya diharapkan agar semua permasalahan diselesaikan dengan musyawarah dan mufakat tanpa harus ke pengadilan. Namun apabila tidak dapat diselesaikan dengan musyawarah maka kepada pencari keadilan di mungkinkan ke pengadilan. Hal ini merupakan budaya Bangsa Indonesia sebagai konsekuensi Negara yang mempunyai dasar Pancasilan. Bahkan setelah di pengadilan hakim masih menganjurkan kepada para pihak untuk untuk berdamai.
} 
tanpa perlu dibuktikan bahwa perbuatan tersebut benar-benar mengurangi persaingan. Sebaliknya perlukah suatu pembuktian yang sulit dilakukan bahwa telah terjadi pengurangan persaingan terhadap suatu perbuatan, yang hampir pasti merusak atau merugikan persaingan. Pertanyaan ini berkaitan dengan adanya ketentuan dalam hukum persaingan yang mempunyai daya jangkau yang sangat luas, sehingga memberi kebebasan bagi hakim untuk menafsirkan apakah seorang dinyatakan melanggar atau tidak melanggar hukum, yang menghambat persaingan atau menghambat perdagangan.

Larangan-larangan yang bersifat Per Se termasuk perbuatan-perbuatan sebagai berikut: 1. penetapan harga secara horizontal, yaitu penetapan harga bersama oleh perusahaan-perusahaan yang memproduksi atau menjual produk atau jasa yang sama. Misalnya beberapa perusahaan semen membuat persetujuan yang menetapkan atau memasok harga semen. 2. perjanjian-perjanjian yang menurut ketentuan-ketentuan yang bersifat eklusif atau memboikot pihak ketiga (group boycotts or exclusionary provisions). ${ }^{23}$

Penetapan harga horizontal terjadi, jika pelaku usaha dari perusahaan yang sejenis melakukan persetujuan bersama untuk menetapkan harga dari produksi atau jasa yang mereka jual, termasuk menaikkan harga, mengatur, mematok harga dari barang-barang atau jasa. Penetapan harga yang dilarang termasuk pula menetapkan harga minimum atau maksimum atau menetapkan produksi barang atau jasa yang boleh diproduksi. Umumnya penjual yang melakukan perjanjian penetapan harga, pembeli juga dapat menetapkan harga dari barang atau jasa yang dibeli. Dalam pemeriksaan atas adanya suatu pengaduan, pihak penggugat yang dibebani untuk membuktikan telah terjadi perjanjian penetapan harga. Penetapan harga ini dalam Section 1 Sherman Act termasuk pelanggaran yang bersifat Per Se. Tidak ada dasar pembenaran yang dapat digunakan untuk meniadakan Per Se Rule terhadap pelanggaran ketentuan ini, termasuk alasan bahwa penetapan harga ini penting untuk melindungi konsumen atau melindungi pesaing-pesaingnya dari kerasnya persaingan. Dalam UULPM, teori Per Se ini diterapkan pada pasal-pasal yang tidak mensyaratkan "yang mengakibatkan atau dapat mengakibatkan terjadinya praktek monopoli atau persaingan tidak sehat" ${ }^{24}$.

Price fixing di Australia (Section 45 A The Trade Practices Act) dianggap sebagai Per Se Illegal, Indonesia nampaknya mengikuti anggapan kedua negara ini. Pasal 5

\footnotetext{
${ }^{23}$ Susanti, Op.cit., hlm. 50 .

${ }^{24}$ Ibid.
} 
ayat (1) UULPM dikatakan bahwa perjanjian penetapan harga horizontal dilarang tanpa melihat efek negatif dari perjanjian tersebut terhadap persaingan. Perjanjian price fixing ini Per Se illegal, maka apakah harga yang ditetapkan itu tinggi atau rendah menjadi tidak relavan, walaupun efek negatif terhadap persaingan itu kecil perjanjian price fixing tetap dilarang. Pemboikotan terjadi jika dua atau lebih pelaku usaha pesaingnya untuk tidak menyediakan barang-barang atau jasanya kepada pelaku usaha tertentu. Misalnya beberapa pengusaha televisi mengadakan perjanjian untuk tidak menjual produksinya kepada penyalur/agen/distributor tertentu atau beberapa pengusaha penyewa mobil mengadakan perjanjian untuk bersama-sama menolak memakai jenis mobil merek tertentu misalnya tidak mau membeli atau menolak menggunakan merek Honda. ${ }^{25}$

Mahkamah Agung AS dahulu memutuskan bahwa perjanjian pemboikotan tersebut adalah pelanggaran yang bersifat $P e r$ Se, tanpa diperlukan pembuktian lebih lanjut, bahwa akibat dari adanya perjanjian pemboikotan tersebut dapat menghambat persaingan. Namun pada tahun-tahun terakhir MA dalam putusanputusannya menggunakan teori Per Se maupun Rule of Reason, berpendapat bahwa hanya pemboikotan tertentu saja yang bersifat Per Se selebihnya akan diperiksa berdasarkan Rule of Reason perlu pembuktian lebih lanjut terhadap akibatnya seperti diuraikan Lawrence A. Sullivan. ${ }^{26}$

\section{Pendekatan Rule of Reason}

\section{Larangan yang bersifat Rule of Reason}

Lain halnya dengan metode pendekatan rule of reason (Rule of Reason Approach). Pendekatan rule of reason dalam persaingan usaha ini merupakan kebalikan lebih luas cakupannya jika dibandingkan dengan per se illegal (per se illegal approach) pendekatan rule of reason ini cenderung berorientasi pada prinsip efisiensi. ${ }^{27}$ Pada sisi lain penggunaan pendekatan rule of reason juga memungkinkan pihak pengadilan melakukan interpretasi terhadap undang-undang anti monopoli. Misalnya dilakukan oleh Mahkamah Agung AS yang menetapkan rule of reason sebagai standar bagi pengadilan untuk mempertimbangkan faktor-faktor persaingan serta menetapkan layak tidaknya suatu hambatan dalam perdagangan. Pendekatan rule of reason tersebut dapat digunakan oleh pengadilan untuk mengetahui serta menilai,

${ }^{25}$ Ibid, hlm.51.

${ }^{26}$ Ibid.

${ }^{27}$ L. Budi Kagramanto, Op. Cit. hlm. 235. 
apakah terdapat hambatan dalam perdagangan atau tidak, apakah hambatan tersebut bersifat mencampuri mempengaruhi atau bahkan mengganggu proses persaingan atau tidak, seperti diuraikan Sullivan Harrison. ${ }^{28}$

Rule of reason berbeda dengan per se illegal. Artinya, di bawah rule of reason untuk menyatakan bahwa perbuatan yang dituduhkan melanggar hukum persaingan, pencari fakta harus mempertimbangkan keadaan disekitar kasus untuk menentukan apakah perbuatan itu membatasi persaingan secara tidak patut, dapat disyaratkan bahwa penggugat dapat menunjukkan akibat-akibat yang menghambat persaingan, tidak berupa apakah perbuatan itu tidak adil ataupun melawan hukum. Teori Rule of Reason pelaksana dari suatu tindakan yang dilarang perlu dibuktikan lebih dahulu sampai seberapa jauh tindakan yang merupakan anti persaingan tersebut akan berakibat kepada pengekangan persaingan pasar. Jadi tidak seperti teori Per Se, dengan memakai teori Rule of Reason tindakan tersebut otomatis dilarang, perbuatan yang dituduhkan tersebut kenyataanya terbukti telah dilakukan. ${ }^{29}$ Kecuali ditentukan sebagai illegal Per se, berdasarkan doktrin per se, kepatutan dan ketidak patutan dari hambatan perdagangan ditentukan secara Rule of Reason. Kepatutan perdagangan ditentukan berdasarkan asas hukum kewajiban untuk menetapkan kepentingan umum yang termuat dalam peraturan perundang-undangan.

Substansi penerapan rule of reason dalam UULPM tergambar dari konteks kalimat yang membuka aternatif interpretasi bahwa tindakan tersebut harus dibuktikan terlebih dahulu akibatnya secara keseluruhan dengan memenuhi unsur-unsur yang ditentukan dalam undang-undang apakah telah mengakibatkan terjadinya praktek monopoli ataupun persaingan usaha tidak sehat. ${ }^{30}$ Substansi UULPM yang menggambarkan prinsip rule of reason adalah pasal-pasal yang mempunyai kalimat membuka peluang bahwa akibat yang ditimbulkan dari tindakan tersebut melanggar UULPM yaitu: a. Pasal 1 ayat (2) Praktek Monopoli adalah pemusatan kekuatan ekonomi oleh satu atau lebih pelaku usaha yang mengakibatkan dikuasainya produksi atau pemasaran atas barang atau jasa tertentu "sehingga menimbulkan persaingan usaha tidak sehat dapat merugikan kepentingan umum". b. Pasal 4 ...yang dapat mengakibatkan terjadinya praktek monopoli dan persaingan usaha tidak sehat. c. Pasal 7 ayat (2), Pasal 22 dan 23...yang dapat mengakibatkan terjadinya

\footnotetext{
${ }^{28}$ Ibid., hlm. 236.

${ }^{29}$ Munir Fuady, Pasar Modal Modern, Citra Aditya Bakti, Bandung, 1999, hlm. 12.

${ }^{30}$ Ningrum Sirait, Op. Cit., hlm. 81.
} 
persaingan usaha tidak sehat. d. Pasal 8 ... sehingga dapat mengakibatkan terjadinya persaingan usaha tidak sehat. Pasal 9 ...sehingga dapat mengakibatkan terjadinya praktek monopoli atau persaingan usaha tidak sehat. e. Pasal 10 ayat (2) ... sehingga perbuatan tersebut: (a) merugikan atau dapat diduga akan merugikan pelaku usaha lain; atau f. Pasal 11, 12, 13, 16, 17,19,... yang dapat mengakibatkan terjadinya persaingan usaha tidak sehat. g. Pasal 14 ...yang dapat mengakibatkan terjadinya persaingan usaha tidak sehat dapat merugikan masyarakat. h. Pasal 18, 20, 26... yang dapat mengakibatkan terjadinya praktek monopoli persaingan usaha tidak sehat. i. Pasal 28 ayat (1) (2) ...yang dapat mengakibatkan terjadinya praktek monopoli persaingan usaha tidak sehat. ${ }^{31}$

Hukum Persaingan Amerika Serikat menganggap perbuatan-perbuatan berikut ini, sebagai per se illegal, yakni price fixing baik vertikal maupun horizontal; tying arrangements; boycotts vertical horizontal; horizontal territorial atau division of markets restraints reciprocal dealing. perbuatan perbuatan seperti vertical territorial restainst; exclusive dealing contracs; requirement contracts; convenants not to compete; merger yang validitasnya dapat bertentangan dengan Pasal 1 Sherman Act, atau pasal 7 Clyton Act. Selebihnya adalah Rule of Reason. Penerapan teori Rule of Reason ini dapat dilihat dari kata yang tertera dari peraturan "mengakibatkan atau dapat mengakibatkan terjadinya praktek monopoli atau persaingan tidak sehat", seperti sudah diuraikan di atas pada beberapa pasal UULPM. Perjanjian-perjanjian atau tindakan-tindakan yang dilarang dalam Pasal-pasal UULPM dapat dikategorikan seperti dilarang secara Per Se, dilarang dengan Rule of Reason, antara Per Se dan Rule of Reason.

\section{Pendekatan Ekonomi}

Saat ini berbagai negara di dunia sedang melakukan perubahan menuju sistem ekonomi pasar (market economy). Dalam sistem ekonomi pasar persaingan merupakan suatu elemen yang menentukan karena pasar akan ditentukan oleh permintaan dan penawaran yang terbuka. Artinya dalam memenangkan pasar dan konsumen, maka pelaku usaha akan melalui proses persaingan. Proses persaingan akan mengukur hasil optimal dengan kemampuan pelaku usaha melakukan efisiensi, inovatif serta alokasi sumber daya yang tidak terbuang percuma melalui strategi yang baik. ${ }^{32}$

\footnotetext{
${ }^{31}$ Ibid., hlm. 82.

${ }^{32}$ Ibid., hlm. 21.
} 
Robert Bork ${ }^{33}$, pemikir dan hakim terkemuka yang banyak memberikan landasan dalam hukum persaingan mengatakan:

Why should we want to preserve competition anyway? The answer is simply that competition providers society with the maximum output that can be achieved at any given time with the resources as its command. Under a competitive regime, productive resources are combined and separated, shuffled and reshuffled in searh for greater profits throught greater efficiency. Each productive resources moves to that employment, where the value of its marginal product, and hence the return paid to it, is greatest. Output is maximized because there is no possible rearrangement of resources that could increase the value to consumers of total output. Competition is desirable, therefore, because it assists in achieving prosperous society and permits individual consumers to determine by their actions what goods and services they want most.

Kenyataannya, proses persaingan belum tentu dilakukan sesuai dengan yang diatur dalam perundang-undangan. Apakah proses persaingan itu dilakukan dengan benar sesuai aturan perundang-undangan yang ada. Persaingan dalam dunia usaha untuk mendapat keuntungan maksimum muncul dalam berbagai bentuk, misalnya dalam harga, jumlah, pelayanan atau kombinasi berbagai faktor yang akan dinilai oleh konsumen.

Pendekatan ekonomi dilakukan KPPU menganalisis terhadap pelanggaran yang dilakukan oleh pelaku usaha berdasarkan relevant market (pasar terkait), market power (kekuatan pasar), barrier to entry (hambatan terhadap pasar) dan pricing strategic (strategi harga) yang diberlakukan oleh si pelaku usaha. ${ }^{34}$ Pendekatan ekonomi ini dilakukan oleh pelaku usaha untuk menentukan, apakah yang dilakukan oleh pelaku usaha itu berpengaruh kepada tingkat persaingan atau tidak serta tidak untuk menentukan apakah tindakan pelaku usaha akan mengakibatkan kondisi perekonomian semakin memburuk atau tidak. Pendekatan ekonomi ${ }^{35}$ akan diuraikan berikut:

\section{Relevant Market (pasar relevan/pasar bersangkutan).}

Pasal 1 angka (10) UULPM menyatakan pasar bersangkutan adalah pasar yang berkaitan dengan jangkauan atau daerah pemasaran tertentu oleh pelaku usaha atas barang jasa yang sama atau sejenis atau substitusi dari barang atau jasa tersebut. Budi L Kagramanto menyatakan relevant market (pasar relevan/pasar bersangkutan) erat kaitannya dengan pengukuran pasar merupakan salah satu tugas penting dalam menganalisa adanya tingkat persaingan pada pasar yang bersangkutan. ${ }^{36}$ 
Mendefinisikan pasar relevan digunakan dua pendekatan yaitu berdasarkan produk yang diperdagangkan (pasar produk) yang nantinya akan menggambarkan barang serta jasa yang diperdagangkan, serta berdasarkan pada jangkauan geografis (pasar geografis) yang akan menggambarkan lokasi produksi dari produsen penjual. ${ }^{37}$

Perlu diperhatikan pada pasar produk adalah apakah terdapat produk substitusi yang terdekat (close substitutes) atau tidak dalam pasar tersebut. Close substitutes, contohnya produk Coca Cola dengan pepsi cola, mie instant, pisau cukur, sepatu lain-lain. Jika produk bersoda (Coca Cola) telah menaikkan harga $10 \%$, apakah konsumen akan beralih mengkonsumsi minuman lain seperti Pepsi Cola. Apabila konsumen tidak beralih ke minuman lain bersoda seperti Pepsi Cola, walau harga naik $10 \%$ produk lain tersedia, maka produk minuman bersoda Coca Cola telah mempunyai market power (penguasaan pasar) yang besar. Jika produk Coca Cola telah berhasil menguasai pasar minuman bersoda maka produsen Coca Cola dapat menaik-turunkan harga sesuai keinginan di atas harga bersaing (competitive market). Dengan demikian produk minuman bersoda Coca Cola telah menurunkan tingkat persaingan tertentu terhadap produk minuman bersoda lainnya, produk Coca Cola telah berhasil membatasi produk pesaing lainnya dalam menaikkan harga produk minuman bersoda. Kondisi seperti ini berdasarkan pendekatan ekonomi tidak diperbolehkan atau dilarang karena melanggar UULPM. ${ }^{38}$

Lain halnya dengan pasar geografis. Pasar geografis ini merupakan pembagian pasar berdasarkan lokasi satu produk tertentu, dimana barang atau jasa itu diproduksi atau dijual. Apakah yang menjadi pasar relevan untuk suatu produk tertentu? Apakah berdasarkan pada luas skala nasional, propinsi, regional ataukah pada suatu pulau bahkan pada pasar global (internasional), itu semua sangat relevan untuk menganalisis adanya tingkat persaingan antara satu pelaku usaha dengan pelaku usaha lain. Apabila produk barang atau jasa itu diproduksi/dijual untuk skala nasional, maka disebut pasar nasional, bila diproduksi untuk kepentingan daerah maka, maka pasarnya disebut sebagai pasar lokal. ${ }^{39}$

Apabila pasar geografis tidak dapat dipastikan seperti diuraikan di atas, maka dapat dilihat berlandaskan hubungan yang ada antara tingkat penjualan dengan

\footnotetext{
${ }^{37}$ Ibid.

${ }^{38}$ Ibid, hlm. 251.

${ }^{39}$ Ibid. hlm. 252.
} 
biaya angkut serta dengan tingkat harga dan perubahannya untuk daerah yang berbeda. Hubungan yang dekat antara harga produk merupakan indikator yang dominan atau kuat, bahwa daerah-daerah tersebut berada dalam pasar geografis. Batas-batas atau faktor-faktor yang berkaitan dengan pasar geografis, misalnya biaya angkut/transport, waktu yang dibutuhkan untuk mengangkut, tarif dan hambatan perdagangan lainnya, adalah peraturan/regulasi, jangkauan iklan atau promosi yang perlu dipertimbangkan lebih lanjut untuk menganalisis, ataukah terdapat atau tidak dugaan/indikasi terjadinya perlanggaran terhadap UULPM yang dilakukan oleh pelaku usaha dalam pasar tersebut. ${ }^{40}$

\section{Market power (kekuatan pasar)}

Kekuatan pasar (market power) erat kaitannya dengan pangsa, karena pelaku usaha dalam kekuatan pasar ini ditentukan berdasarkan pada pasar yang dikuasainya. Pangsa pasar di sini mencerminkan kekuatan pasar dari pelaku usaha/ produsen, kekuatan pasar tersebut dapat digunakan untuk mengatur harga supra kompetitief atau untuk menghambat adanya persaingan (barrier to entry). Cara yang dapat dilakukan untuk pengukuran pangsa pasar adalah dengan nilai uang, menggunakan satuan penjualan (misalnya produk homogen: pertanian, logam), satuan produksi (misalnya produk heterogen) serta berdasarkan pada kapasitas produksi atau ukuran cadangan untuk manufaktur. ${ }^{41}$

Menentukan seberapa besar pangsa pasar yang telah dikuasai oleh pelaku usaha, maka diperlukan suatu pengukuran tersendiri dalam suatu pasar yang bersangkutan. Pengukuran pasar ini penting artinya karena dapat digunakan untuk melihat ada tidaknya posisi dominan yang dimiliki oleh pelaku usaha dalam suatu pasar beserta akibat yang kemungkinan akan muncul, jika beberapa pelaku usaha yang memiliki pasar relevan berupaya untuk menggabungkan diri (merger). Pengukuran yang paling lazim popular yang sering digunakan melalui penjualan (unit). Juga dapat dilihat berdasarkan penjualan di masa lalu, termasuk hasil penjualan yang sedang berjalan, sekalipun itu terhadap penjualan pada tingkat/ tangan kedua. Pendekatan lain yang dapat digunakan untuk pengukuran pasar yaitu berdasarkan kapasitas produksi.

\footnotetext{
${ }^{40}$ Ibid.

${ }^{41}$ Ibid
} 
Suatu perusahaan yang mempunyai kapasitas produksi dapat menggunakan kapasitasnya untuk menghalangi pelaku usaha lainnya masuk pada pasar yang bersangkutan (barrier to entry) dengan cara menggerojok/membanjiri pasar dengan produk barang maupun jasa yang dihasilkannya. Ada juga pendekatan pasar berdasarkan frekuensi dalam rangka memenangkan tender tertentu di daerah tertentu dalam jumlah/nilai tertentu. Hal ini dapat dilakukan terutama pada perusahaan yang operasinya dalam kegiatan tender, misalnya tender pada proyek pengeboran minyak lepas pantai ataupun pembangunan infrastruktur pada kota tertentu. ${ }^{42}$

L Budi Kagramanto mengatakan bahwa ketentuan tersebut erat kaitannya dengan Pasal 19 UULPM yang mengatur tentang penguasaan pasar. Pasal 19 UULPM mengatakan pelaku usaha dilarang melakukan satu atau beberapa kegiatan baik sendiri maupun bersama dengan pelaku usaha lain yang dapat mengakibatkan terjadinya praktek monopoli persaingan usaha tidak sehat. Kegiatan yang dilarang dalam UULPM adalah: menolak atau menghalangi pelaku usaha tertentu untuk melakukan kegiatan usaha yang sama pada pasar bersangkutan atau; menghalangi konsumen atau pelanggan pelaku usaha pesaingnya untuk tidak melakukan hubungan usaha dengan pelaku usaha pesaingnya itu atau; membatasi peredaran atau penjualan barang atau jasa pada pasar yang bersangkutan; atau melakukan praktek diskriminasi terhadap pelaku usaha tertentu. ${ }^{43}$

\section{Barrier to Entry (hambatan masuk pada pasar bersangkutan)}

Hambatan masuk ke pasar bersangkutan (barrier to entry) bagi pelaku usaha merupakan persoalan serius dalam rangka melakukan kegiatan usahanya secara lancer. Salah satu cara yang ditempuh oleh pelaku usaha adalah mengurangi hambatan untuk masuk ke pasar bersangkutan ini merupakan metode yang baik atau dapat dikatakan sebagai hal yang bermanfaat bagi persaingan usaha. Dengan berusaha untuk mempertahankan pelaku usaha pesaing yang beragam karakternya serta berusaha untuk mencegah terjadinya hambatan masuk ke pasar bersangkutan (barrier to entry) maka setidaknya penegakan hukum persaingan usaha menuju arah yang benar. Tanpa adanya barrier to entry uang diciptakan oleh pemerintah (tidak ada distorsi oleh pemerintah), maka perusahaan besar pada pasar yang

\footnotetext{
${ }^{42}$ Ibid. hlm. 253.

${ }^{43}$ Ibid. hlm. 254.
} 
terkonsentrasi terpaksa harus melakukan efisien terhadap perubahan yang terjadi pada pasar tersebut, karena kehadiran pelaku usaha baru yang mampu menembus pasar tersebut. ${ }^{44}$

Kekhawatiran akan masuknya pelaku usaha pesaing baru yang lebih inovatif agresif akan memaksa pelaku usaha lama mencari terobosan yang bermanfaat inovasi terbaru atas produk serta proses produksi barang atau jasa tertentu. Kondisi demikian tentunya dalam konteks (asumsi), dimana tidak terdapat tindakan anti persaingan atau tidak adanya distorsi yang diciptakan oleh pemerintah yang sifatnya dapat menghambat pelaku usaha untuk masuk ke pasar yang bersangkutan. Sebenarnya barrier to entry sangat relevan bagi kebijakan persaingan yakni jika terdapat lima kemungkinan: a. untuk mengetahui berapa banyak jumlah perusahaan yang berhasil masuk pada pasar yang bersangkutan untuk membendung/mencegah terjadinya kenaikkan harga yang dilakukan oleh perusahaan (pemain/pelaku usaha) yang lama; b. untuk mengetahui apakah terdapat perusahaan baru yang berhasil masuk ke pasar tersebut untuk melakukan merger; c. untuk mengevaluasi apakah barrier to entry memang sengaja diciptakan untuk merusak persaingan yang sudah ada terbentuk dengan baik sebelumnya; d. ataukah barrier to entry tersebut sudah ada sejak semula lahir secara alamiah dari suatu perubahan bentuk pasar; e. untuk mengetahui apakah terdapat biaya (cost) yang harus ditanggung oleh pelaku usaha yang berhasil masuk ke pasar baru tersebut berbeda-beda. ${ }^{45}$

L. Budi Kagramanto ${ }^{46}$ mengatakan Barrier to entry merupakan suatu keadaan dimana pelaku usaha pesaing tidak dapat memasuki dalam bidang usaha tertentu pada pasar bersangkutan, karena adanya penguasaan kekuatan pasar yang lebih besar yang dilakukan oleh perusahaan-perusahaan yang memiliki kedudukan yang lebih kuat. Barrier to entry juga merupakan salah satu cara yang ditempuh oleh satu atau beberapa pelaku usaha yang telah menguasai pasar sebelumnya, untuk menghambat pelaku usaha lain yang dianggap memiliki potensi serta kemampuan bersaing, sehingga mengurangi keuntungan yang akan diraihnya. Adapun pelaku usaha pesaing adalah pelaku usaha yang memiliki kegiatan usaha yang sama/ sejenis pada pasar yang sama atau berada di daerah pemasaran yang bersangkutan. Jelas bahwa melalui pendekatan ekonomi barrier to entry dapat digunakan sebagai

\footnotetext{
${ }^{44}$ Ibid. hlm. 255.

${ }^{45}$ Ibid. hlm .256.

${ }^{46}$ Ibid. hlm. 257.
} 
suatu pendekatan untuk menganalisis apakah terdapat indikasi atau dugaan pelanggaran UULPM oleh pelaku usaha.

\section{Pricing Strategic (strategi harga)}

Dalam pendekatan perilaku, harga merupakan salah satu tolok ukur untuk mengamati, apakah terdapat dugaan/indikasi pelanggaran terhadap UULPM atau tidak. UULPM merupakan instrumen pengawasan terhadap potensi pelanggaran larangan penetapan harga, diskriminasi harga, jual rugi, banting harga, kartel, oligopsoni, resale price maintenance yang dilakukan oleh pelaku usaha dalam rangka menentukan harga tingkat harga yang ada pada pasar tertentu. ${ }^{47}$ Diperlukan suatu pengetahuan yang memadai mengenai proses terjadinya/pembentukan harga pasar, pertimbangannya apa serta strategi apa yang sekiranya dapat digunakan oleh pelaku usaha untuk menentukan harga atas produk yang dihasilkannya. Hal yang perlu mendapat perhatian adalah pentingnya untuk mengamati posisi dominan penguasaan pasar yang dimiliki pelaku usaha nantinya akan menjadi indikator dalam melakukan analisis, apakah dalam pasar tersebut terdapat persaingan atau tidak. Tolok ukur penguasaan pasar posisi dominan inipun akan menggunakan harga sebagai komponen utamanya, yakni dengan melihat kemampuan pelaku usaha dalam mempengaruhi harga. ${ }^{48}$

Strategi harga yang digunakan pelaku usaha adalah: 1. penetapan harga yang dapat menghasilkan keuntungan yang lebih besar; 2. menyerap surplus dari konsumen/pembeli yang terdiri dari: dikriminasi harga (tingkat pertama, kedua ketiga), dua bagian tarif, commodity building (penggabungan dua komoditas dalam satu harga), harga grosir (block pricing); 3. strategi harga untuk biaya serta struktur permintaan khusus terdiri atas: harga sibuk tidak sibuk (peak-load pricing), subsidi silang, penetapan harga berdasarkan hari-hari besar (lebaran, natalan, tahun baru ataupun hari kemerdekaan negara); 4. strategi harga pada persaingan harga ketat; price matching, inducing brand loyality (menonjolkan pada kesetiaan merek tertentu); 5 . harga acak (trandomized pricing); 6. penetapan harga lain yang antikompetitief, terdiri atas; penetapan harga di bawah biaya marginal (predatory pricing/banting harga), penetapan harga maksimal penetapan harga minimum, pemberian diskon harga. ${ }^{49}$

Pasal 5 UULPM menetapkan larangan yang tegas terhadap penetapan harga, tanpa perlu menganalisis akibat dari penetapan harga terhadap persaingan atau

\footnotetext{
${ }^{47}$ Ibid.

${ }^{48}$ Ibid. hlm. 258.

${ }^{49}$ Ibid. hlm. 259.
} 
konsumen, dalam hal ini digunakan pendekatan per se illegal. Sebagai contoh KPPU telah menetapkan putusan terhadap perkara No. 26/KPPU-L/2007 Tentang Kartel Short Massage Service (SMS) yaitu dugaan pelanggaran terhadap Pasal 5 UULPM. Dugaan pelanggaran tersebut adalah penetapan harga tarif SMS off-net (short message service antar operator) yang dilakukan oleh para operator penyelenggara jasa telekomunikasi pada periode 2004 sampai dengan 1 April 200850. Penetapan harga dengan sendirinya dapat menghambat persaingan, yang akhirnya merugikan konsumen, karena periode 1994 - 2004 hanya terdapat tiga operator telekomunikasi seluler di Indonesia dan berlaku satu tarif SMS sebesar Rp. 350,00-. Namun demikian tidak ditemukan adanya kartel diantara operator pada saat itu karena tarif yang terbentuk terjadi karena struktur pasar yang oligopoli.

Tim Pemeriksa KPPU menemukan beberapa klausula penetapan harga SMS yang tidak boleh lebih rendah dari Rp 250,- dimasukkan ke dalam Perjanjian Kerja Sama (PKS) Interkoneksi antara operator sebagaimana dalam Matrix Klausula ${ }^{51}$. Dalam hal ini unsur-unsur penetapan harga adalah suatu perjanjian eksplisit yang ditetapkan oleh pelaku usaha, dalam kasus ini adalah isi Perjanjian Kerja Sama Interkoneksi antara operator ini antara Terlapor I: PT Excelkomindo Pratama, Tbk., Terlapor II: PT Telekomunikasi Selular, Terlapor IV: PT Telekomunikasi Indonesia, Tbk., Terlapor VI: PT Bakrie Telecom, Terlapor VII: PT Mobile-8 Telecom, Tbk.,Terlapor VIII: PT Smart Telecom terbukti secara sah meyakinkan melanggar Pasal 5 UULPM.

Pada Juni 2007, berdasarkan hasil pertemuan BRTI (Badan Regulasi Telekomunikasi Indonesia) dengan Asosiasi Telepon Seluler Indonesia (ATSI), ATSI mengeluarkan surat untuk meminta kepada seluruh anggotanya untuk membatalkan kesepakatan harga SMS yang kemudian ditindaklanjuti oleh para operator. Namun demikian Tim Pemeriksa melihat tidak terdapat perubahan harga SMS off-net yang signifikan di pasar ${ }^{52}$. Dan April 2008 terjadi penurunan tarif dasar SMS off-net di pasar.

Penerapan per se illegal sudah tepat terhadap tindakan penetapan harga ini yang dilakukan oleh KPPU sudah tepat karena penetapan harga tersebut diakomodir oleh pasar. Karena penetapan harga disini dimaksudkan, tanpa perlu menganalisis akibat dari penetapan harga terhadap persaingan atau konsumen, dan perjanjian penetapan harga tersebut adalah perjanjian diantara pelaku usaha dalam hal ini

\footnotetext{
${ }^{50}$ Alum Simbolon, 2011, Kedudukan Hukum Komisi Pengawas Persaingan Usaha Dalam Melaksanakan Kewenangan Penegakan Hukum Persaingan Usaha, Disertasi, Fakultas Hukum Universitas Gadjah Mada, Yogyakarta, hlm. 361.

${ }^{51}$ Putusan KPPU No. 26/KPPU-L/2007, dalam Disertasi Alum Simbolon, Yogyakarta, 2011, hlm 362.

${ }^{52}$ Ibid.
} 
antara PT Excelkomindo Pratama, Tbk., PT Telekomunikasi Selular, PT Telekomunikasi Indonesia, Tbk., PT Bakrie Telecom, PT Mobile-8 Telecom, Tbk., PT Smart Telecom, untuk menaikkan atau menetapkan harga guna membatasi persaingan antar perusahaan dan meraih keuntungan yang lebih tinggi.

Berdasarkan pada strategi harga yang diciptakan oleh pelaku usaha, maka jelas bahwa melalui pendekatan ekonomi, melalui strategi harga tersebut nantinya dapat digunakan sebagai suatu pendekatan untuk menganalisis apakah terdapat indikasi atau dugaan pelanggaran terhadap UULPM yang dilakukan oleh pelaku usaha. Apabila ada suatu pelanggaran terhadap UULPM yang dilakukan oleh pelaku usaha, maka terhadap pelanggaran tersebut KPPU dapat menghukum ataupun menjatuhkan sanksi kepada pelaku usaha. Sanksi yang dijatuhkan oleh KPPU adalah sanksi administratif dan denda seperti yang diatur dalam Pasal 47 UULPM.

KPPU dalam menyelesaikan perkara persaingan usaha harus memperhatikan, mencermati dan menganalisa kasus perkara tersebut dengan baik, bahwa pendekatan hukum dan pendekatan ekonomi harus dilakukan berhubung persoalan yang diselesaikan adalah persoalan hukum di bidang ekonomi. Oleh karena itu, latar belakang pendidikan KPPU juga harus diperhatikan, bahwa untuk dapat menyelesaikan perkara dengan baik maka pendidikan dengan background hukum harus ada sejumlah $45 \%$ dan background pendidikan ekonomi sejumlah $45 \%$ sangat dibutuhkan di sana. Kemudian dapat ditambahkan dengan dengan background pendidikan lainnya $10 \%$ dari background pendidikan lainnya untuk menyempurnakan pendapat dan analisis dalam memutus perkara persaingan usaha. Hal ini sangat menentukan kualitas dari putusan, sebab dengan background pendidikan seperti disebutkan diatas maka putusan yang dihasilkan optimal.

Setiap orang datang menyampaikan laporannya kepada KPPU dengan harapan untuk mencari perlindungan dan keadilan yang seadil-adilnya, maka jikalau perkara diputus oleh komisioner yang tidak tepat bidang keilmuannya maka dapat dibayangkan putusan yang dihasilkan, tentunya kemungkinan ada yang kurang tepat karena tidak memahami duduk persoalan. Berhubung juga KPPU dalam memutus perkara harus melakukan dua pendekatan yaitu pendekatan hukum (yuridis approach) dan pendekatan ekonomi (economic approach), maka latar belakang pendidikan juga harus disesuaikan agar hasilnya optimal.

Perkara yang diselesaikan dalam hukum persaingan usaha adalah perkara hukum dibidang ekonomi, maka tentunya tepat jika KPPU dalam menyelesaikan 
perkara persaingan usaha melakukan dua pendekatan yaitu pendekatan hukum dan pendekatan ekonomi. Artinya bahwa analisa hukum sangat dibutuhkan dalam penyelesaian perkara tersebut dan analisa ekonomi juga sangat dibutuhkan dalam penyelesaian perkara tersebut. Jadi keduanya saling mendukung sehingga putusannya qualified, karena sudah memperhatikan analisis kedua bidang ilmu ini.

\section{Penutup}

Berdasarkan uraian di atas dapat disimpulkan bahwa pendekatan yang dilakukan oleh KPPU dalam menentukan pelangaran terhadap hukum persaingan usaha adalah pendekatan per se illegal yaitu larangan yang jelas tegas terhadap perilaku yang sangat mungkin merusak persaingan dan bukan pendekatan rule of reason. Penerapan per se illegal sudah tepat terhadap tindakan penetapan harga yang dilakukan oleh KPPU karena penetapan harga tersebut diakomodir oleh pasar.

\section{Daftar Pustaka}

Anggraini, Tri Maria, Per Se Illegal dan Rule of Reason, UI Press, Jakarta, 2003.

Budi, L Kagramanto, Larangan Persekongkolan Tender (Perspektif Hukum Persaingan Usaha, Penerbit Srikandi, Surabaya, 2008.

Fuady, Munir, Pasar Modal Modern, Citra Aditya Bakti, Bandung, 1999.

Harahap, M. Yahya, Beberapa Tinjauan Tentang Permasalahan Hukum (II), Citra Aditya Bakti, Bandung, 1997.

Mertokusumo, Soedikno, Penemuan Hukum sebuah Pengantar, Penerbit Liberty Yogyakarta, 1996.

Nugroho, Susanti Adi, Naskah Akademis Tentang Persaingan Usaha Anti Monopoli, Mahkamah Agung -RI, Jakarta, 2005.

Sirait, Ningrum, Natasya, Hukum Persaingan di Indonesia, Penerbit Pustaka Bangsa Press, Medan, 2004.

Simbolon, Alum, Kedudukan Hukum Komisi Pengawas Persaingan Usaha dalam Melaksanakan Kewenangan Penegakan Hukum Persaingan Usaha, Disertasi, Fakultas Hukum Universitas Gadjah Mada, Yogyakarta, 2011.

Undang-Undang Dasar 1945.

UU No. 5 Tahun 1999 tentang Larangan Praktek Monopoli Persaingan Usaha TidakSehat.

Keputusan Presiden Republik Indonesia Nomor 75 Tahun 1999 tentang Komisi Pengawas Persaingan Usaha. 